Article

\title{
Low-Carbon Initiatives of Logistics Service Providers: The Perspective of Supply Chain Integration
}

\author{
Cheng Qian $『$, Shenghui Wang, Xiaohong Liu * and Xueying Zhang \\ Business School, Central University of Finance and Economics, Beijing 100081, China; \\ qiancheng@cufe.edu.cn (C.Q.); wangshenghui@cufe.edu.cn (S.W.); zhangxy_cufe@163.com (X.Z.) \\ * Correspondence: xliu@cufe.edu.cn
}

Received: 8 May 2019; Accepted: 10 June 2019; Published: 12 June 2019

check for updates

\begin{abstract}
Logistics service providers (LSPs) are under tremendous pressure in the fight against global climate change. While existing research has examined the operational importance of LSPs in decarbonizing supply chains, the strategic perspective of LSPs on low carbon supply chains has not received enough attention. Motivated by the evolving role of LSPs from a service provider to a resource integrator in the supply chain, drawing on the relational view of inter-organizational competitive advantage, this paper focuses on LSPs' low-carbon supply chain integration (SCI) and empirically investigates its drivers and outcomes. Data from 124 Chinese LSPs shows that LSPs' corporate environmental responsibility and customer environmental requirement have positive relationships with LSPs' low-carbon SCI, and that LSPs' low-carbon SCI is positively related to LSPs' environmental and financial performance. In addition, LSPs' environmental performance is found to have a positive relationship with LSPs' financial performance. These findings not only provide new insights for LSPs' low-carbon supply chain initiatives, but also highlight the importance of SCI as a strategic approach in low-carbon supply chain management.
\end{abstract}

Keywords: logistics service providers; low-carbon initiatives; supply chain integration; corporate environmental responsibility; relational view

\section{Introduction}

Climate change has been a global challenge. According to the United Nations, weather events are becoming more extreme and greenhouse gas emissions are now at their highest levels in history [1]. As countries around the world have brought climate action to the top of their economic agenda, there is growing pressure on reducing carbon emissions from supply chain management (SCM). The logistics industry, characterized by enormous energy consumption and carbon emissions, is under tremendous pressure in the fight against global climate change [2].

Despite the challenge of low-carbon supply chain initiatives, an opportunity for the logistics industry lies in the evolving role of the logistics service providers (LSPs), from a service provider to a resource integrator in supply chains [3]. In addition to providing traditional logistics management activities (e.g., transportation, warehousing, order processing, and related IT support), LSPs have evolved into a leadership role and have taken on a more proactive manner for customers by organizing networks, sharing information, managing assets, and reducing inventory [4]. A typical example is United Parcel Service, Inc. (UPS), who has evolved from a provider of simple delivery services to offering complete distribution management and network design [4]. Although previous research has examined the operational importance of LSPs in decarbonizing supply chains [5], the strategic role of LSPs in low carbon supply chains has not received enough attention.

Further, the increase of logistics outsourcing requires management of the relationship between LSPs and logistics users. In this background, external supply chain integration (SCI) between LSPs 
and their customers has drawn increasing attention from SCM researchers [6-8]. It has been shown that SCI between LSPs and their customers can help maintain a stable logistics resource provision and contribute to the relationship between LSPs and their customers [7]. Despite the substantial amount of research on SCI between LSPs and their customers, the majority of these researches focus on manufacturer-initiated SCI, and there is a dearth of research on the antecedents and effectiveness of SCI from the perspective of LSPs, let alone in the research on low-carbon supply chains. To fill the gap of SCI from the perspective of LSPs, this paper considers SCI as LSPs' strategic low-carbon initiatives in the supply chain, and investigates the drivers and outcomes of LSPs' low-carbon SCI.

Based on the relational view of inter-organizational competitive advantage [9], we argue that the corporate environmental responsibility (as an internal driver) and the customer environmental requirement (as an external driver) have positive relationships with LSPs' low-carbon SCI, since both drivers can shape the buyer-supplier relationship in the collaboration paradigm of supply chains [10]. Further, we propose a positive relationship between LSPs' low-carbon SCI and LSPs' firm performance, including the environmental performance and financial performance.

The findings of this research contribute to the literature in two aspects. First, this research contributes to the research on low-carbon SCM by providing empirical evidence that SCI can be an effective approach to achieve the goals of environmental and financial performance simultaneously. Second, it also extends the existing research on SCI by focusing on the perspective of LSPs rather than manufacturers in the supply chain, which enriches the growing research on SCI as a low-carbon supply chain initiative.

The remainder of this article is structured as follows. In the next section, we review the literature on low-carbon SCM and SCI. In Section 3, we build on the existing research to derive five research hypotheses. In Section 4, we introduce our data collection approach, including sampling and measures. Subsequently, we present our analysis and results, followed by a discussion of results. The last section concludes with a discussion of limitations and future research.

\section{Literature Review}

\subsection{Low-Carbon Supply Chain Management}

Low-carbon SCM is defined as "a strategy that integrates $\mathrm{CO}_{2}$ or $\mathrm{CO}_{2}$ equivalent or greenhouse gas (GHG) emissions, either as a constraint or as an objective in supply chain design and planning" [11] (p. 399). It is considered as the combination of low-carbon operations management and SCM in response to climate change, focusing on activities that reduce the carbon footprint in supply chains [12], such as low-carbon products, production, processes, and logistics. A substantial amount of research has been conducted on low-carbon SCM, mainly focusing on the functional and operational aspects of SCM concerning carbon performance and emission issues, as well as the measurement issues of carbon footprint [13].

Low-carbon SCM is closely related to green SCM which is defined as "integrating environmental thinking into supply-chain management" [14] (p. 54). While green SCM is concerned with a broad scope of environmental problems such as pollution control, natural resource conservation, and waste management, low-carbon SCM mainly focuses on GHG emission reduction [11]. Although some researchers argue that the drivers, barriers, and performance outcomes of low-carbon SCM should be similar to those of green SCM [12], the empirical findings on the determinants and effectiveness of low-carbon SCM have been inconclusive. For instance, although environmental regulation has been shown to be a determinant of low-carbon initiatives [12], they are not found to motivate extended supply chain practices for energy saving and emission reduction [15], and are not found to determine inter-firm collaborations on carbon emission reduction either [16].

In addition, there exists a stream of literature on low-carbon SCM which specifically focuses on the logistics industry [17-20]. For example, Colicchia et al. [18] developed a framework for LSPs' initiatives towards environmental sustainability, and identified collaboration with customers as a 
critical inter-organizational environmental practice. Herold and Lee [20] provided a comprehensive review on carbon management research in the logistics and transportation sector, and called for research on a strategic management approach to improve carbon management in the logistics industry. Although attempts of research have been made on carbon disclosure strategies of LSPs [21-23], there has been no research considering SCI as a carbon management strategy of LSPs.

\subsection{Supply Chain Integration}

SCI refers to "the degree to which a manufacturer strategically collaborates with its supply chain partners and collaboratively manages intra- and inter-organization processes" [6] (p. 59), where the inter-organization (or external) SCI includes collaboration that takes place between a focal firm and its suppliers and customers. With the evolving strategic importance of LSPs in supply chains, there is a rapidly growing amount of research on the effectiveness of SCI between a focal firm and its LSPs on firm performance. For example, Jayaram and Tan [24] point out the importance of a firm integrating with third-party logistics providers in SCM, showing that firm performance was positively related to information integration, 3PL selection criteria, performance evaluation, and relationship building. Huo et al. [7] empirically examined the roles of dependence and trust when firms integrate their third-party logistics providers. The common feature of these researches is that they all take the perspective of the focal manufacturing firms in the supply chain; the amount of research on SCI from the perspective of LSPs is limited [25-27].

Vachon and Klassen [28] are among the first who explored the relationship between SCI and green supply chain practices. They found empirical evidence for the positive relationship between technological integration and collaborative green practices in the supply chain. Using a survey of North American manufacturers, Vachon and Klassen [29] show the benefits of collaborative green practices in the supply chain. Drawing on research on low-carbon SCM and SCI, Mao et al. [8] define low-carbon SCI as "the extent to which a firm integrates with its suppliers and customers as well as internal sources and capabilities in order to green production processes and reduce environmental impacts" (p. 355). They empirically show that external low-carbon SCI improves both environmental performance and financial performance, whilst internal low-carbon SCI helps to improve a firm's environmental performance but hinders a firm's financial performance. Nevertheless, to the best of our knowledge, there has been no research on low-carbon SCI from the perspective of LSPs, and the drivers and outcomes of LSPs' low-carbon SCI remain unclear.

\section{Hypothesis Development}

Drawing on the relational view of inter-organizational competitive advantage [9], we propose that customer environmental requirement and corporate environmental responsibility may act as external and internal drivers of LSPs' low-carbon SCI, respectively, and that LSPs' low-carbon SCI may increase the LSPs' environmental and financial performances. The conceptual framework and the hypothesized relationships are shown in Figure 1.

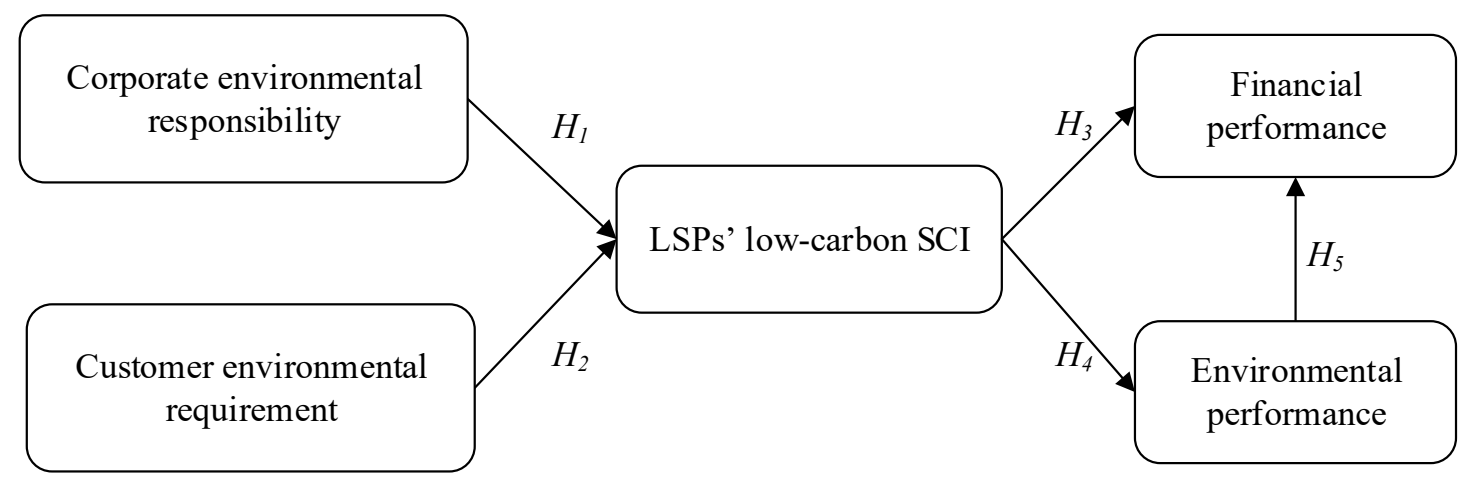

Figure 1. Theoretical framework. LSPs—logistics service providers; SCI—supply chain integration. 


\subsection{Drivers of LSPs' Low-Carbon SCI}

Two streams of research are related to the drivers of LSPs' low-carbon SCI. One is on the internal and external drivers of green or low-carbon initiatives in the supply chain. Previous literature on green SCM has identified a variety of drivers of green supply chain initiatives, such as clear environmental vision and policy statement [30], customer pressure [12,31], and regulatory pressure [18,32]. Damert et al. [12] empirically show that buyer requests to reduce GHG emissions (as a source of normative and coercive forces) and climate change regulation can motivate the suppliers to implement low-carbon initiatives. The other stream of research is on the antecedents of SCI, such as selection criteria [24], organizational cultures [33], strategic supply chain relationship [34], and dependence [7].

As an extension of the resource-based view of the firm which focuses on rare, valuable, non-substitutable, and difficult-to-imitate resources within the firm [35], the relational view of inter-organizational competitive advantage argues that the critical resources of a firm may extend beyond firm boundaries [9,36]. Building on the relational view, Chen and Paulraj [10] propose a collaborative paradigm stating that the supply chain is a network of interdependent relationships developed and fostered through strategic integration. In this collaborative paradigm, SCI not only serves as an effective strategy to establish and strengthen the buyer-supplier relationship, but also can be the outcome of enhanced buyer-supplier relationships [30]. This is also confirmed by empirical research in green SCM that the buyer-supplier relationship influences green supply chain collaboration through asset specificity, volume uncertainty, transaction frequency, and competitive environment [37].

Some researchers have shown that in the outsourcing of logistics service, the buyers can put high values on the LSPs' capabilities in meeting the environmental requirement $[5,38]$. Based on the relational view, we propose that customer environmental requirement exerts external pressures on LSPs, which motivate the LSPs to adopt the strategy of low-carbon SCI, in order to establish, maintain, and foster the relationships with their customers. Thus, we hypothesize that customer environmental requirement can act as the external driver of LSPs' low-carbon SCI.

H1. As customer environmental requirement increases, LSPs' low-carbon SCI increases.

Further, we propose corporate environmental responsibility as the internal driver of LSPs' low-carbon SCI. Environmental responsibility has been considered as one the most prominent aspects of corporate social responsibility $[39,40]$, representing voluntary commitment to sustainable development and a long-term relationship with the stakeholders. Although corporate responsibility has traditionally been considered within the boundaries of a firm, some scholars have extended it to the inter-organizational network in the supply chain [18,40,41]. For instance, Kovács [41] reveals that the supplier takes more environmental responsibility and engages in more environmental collaborations in the supply chain when the role of the supplier becomes more important in the supply chain.

There also exists empirical evidence showing that environmental responsibility acts as an internal driver of the green supply chain initiatives, such as green purchasing, design for environment, and reverse logistics [29,42]. Hsu et al. [42] show that environmental responsibility motivates firms in Malaysia to produce products with reduced material consumption and energy during use. From the relational view, we propose that LSPs' corporate environmental responsibility can motivate the initiatives of low-carbon SCI, in order to establish environmental reputations and foster a long-term relationship with the stakeholders in the supply chain. Hence, we propose the following hypothesis:

H2. As LSPs' corporate environmental responsibility increases, LSPs' low-carbon SCI increases.

\subsection{Outcomes of LSPs' Low-Carbon SCI}

Similar to the drivers of LSPs' low-carbon SCI, there also exist two streams of research related to the outcomes of LSPs' low-carbon SCI. One is on the effects of green or low-carbon supply chain initiatives on firm performance. While many studies show that the green supply chain initiatives positively affect firms' environmental performance and economic performance [32], some researchers 
have shown that green supply chain initiatives may improve the environmental performance but not the economic performance [43], or improve the economic performance indirectly through their effects on environmental performance [44]. The other stream of research is on the effect of SCI on firm performance. Although SCI does not necessarily improve all aspects of firm performance [8], many researchers have found positive relationships between SCI and firms' operational performance [24], logistics performance [45], service performance [27], supply chain relationship [26], and financial performance $[7,25]$.

Since LSPs' low-carbon SCI represents a combination of low-carbon supply chain initiatives and external SCI initiated by LSPs, we consider its effect on both the environmental performance and financial performance of LSPs. From the relational view, Vachon and Klassen [29] point out two direct outcomes of environmental collaboration (i.e., the development of knowledge-sharing routines and the development of the capability to integrate external resources) and argue that such a combination of resources can lead to a competitive advantage. Thus, low-carbon SCI concentrates on the generation and development of inter-organizational environmental resources and capabilities through interaction and knowledge-sharing with customers, which fosters the buyer-supplier relationship, emission reduction, environmental reputation, inter-organizational learning and know-how, and technologies, all of which can bring competitive advantage to the LSPs $[9,28,45]$.

Specifically, when LSPs integrate carbon emission issues in supply chain design and planning at the inter-organizational level, it can help reduce unnecessary energy use, waste emissions, and GHG emissions, not only in logistics activities but also in extended activities along the supply chain $[2,16]$. Further, as the inter-firm collaboration fosters long-term buyer-supplier relationships, customers could provide LSPs with access to critical resources such as materials, environmental standards, or technologies [41], which enables inter-organizational learning and knowledge transfer. The inter-organizational learning is a resource that can instill additional capabilities in organizations [29] and develop other resources, such as environmental reputation or trusted brands [46]. In addition, there has been empirical evidence showing that collaborative green supply chain initiatives are positively associated with environmental performance $[36,46]$. Thus, we propose a positive relationship between LSPs' low-carbon SCI and LSPs' environmental performance.

\section{H3. As LSPs' low-carbon SCI increases, LSPs' environmental performance increases.}

Further, LSPs' inter-organizational integration enables LSPs to improve their financial performance through increased efficiency and cost advantage. With the LSPs' low-carbon SCI, the inter-organizational coordination can increase the operational efficiency of processes and recycling of wastes, and reduce disposal costs, penalties, and future costs of compliance [47]. Operational efficiency can also be gained from increased information sharing, knowledge transfer, and relationship building with the customers [24], as well as enhanced inter-organizational learning capability [27]. Thus, we propose a positive relationship between LSPs' low-carbon SCI and LSPs' financial performance.

H4. As LSPs' low-carbon SCI increases, LSPs' financial performance increases.

A positive relationship between environmental performance and economic performance has been proposed and tested in previous empirical research on green supply chain initiatives $[16,44,48]$, mainly from two perspectives. First, the environmental reputation from low-carbon SCI can improve the environmental image of LSPs, which can increase market share, market opportunities, as well as support from the society and government, leading to increased financial performance [47]. Second, enhanced environmental performance is associated with environmentally sustainable product design and logistics, which can also improve economic performance by improving resource efficiency [48]. Based on the above analysis, we propose the following hypothesis:

H5. As LSPs' environmental performance increases, LSPs' financial performance increases. 


\section{Research Design}

\subsection{Data and Sample}

To test our theoretical hypotheses, a survey link was randomly sent to 450 3PLs in Guangdong, China through collaboration with local professional logistics institutions. Guangdong province is one of the most developed industrial provinces in South China, with the highest GDP (9730 billion yuan in 2018) and the most highly developed logistics industry $(2,016,000$ logistics companies in 2017) in China [49]. A total of 124 valid responses were received, representing a response rate of $27.6 \%$. To examine the possibility of nonresponse bias, we tested the difference in the responses of early and late waves ( 80 and 44 responses, respectively) of returned surveys [50]. The t-test showed no significant difference between random subsamples of the early and late responses at the $p>0.05$ level, suggesting that nonresponse bias should not be a serious problem in this study. The possibility of common method bias was also examined using Harman's single-factor test. No single factor emerged from the factor analysis, and the first factor accounted for $41.83 \%$ of the variance, which was lower than $50 \%$ of the total variance. Hence, the common method bias was not a problem here.

Table 1 shows the sample distribution of the number of employees and turnover. As to the firm size in the sample, the majority of the LSPs were small and medium-sized enterprises (SMEs) with less than 200 employees and a turnover of less than 20 million yuan; only $21.77 \%$ of the LSPs had more than 500 employees and only $20.97 \%$ had a turnover higher than 100 million yuan.

Table 1. Sample description.

\begin{tabular}{lll}
\hline & Observations & Percentage (\%) \\
\hline Number of employees & & \\
$<100$ & 41 & 33.06 \\
$100-200$ & 34 & 27.42 \\
$201-500$ & 22 & 17.74 \\
$>500$ & 27 & 21.77 \\
Turnover (million yuan) & & \\
$<5$ & 23 & 18.55 \\
$5-10$ & 29 & 23.39 \\
$11-20$ & 14 & 11.29 \\
$21-50$ & 22 & 17.74 \\
$51-100$ & 10 & 8.06 \\
$>100$ & 26 & 20.97 \\
\hline
\end{tabular}

\subsection{Measures}

The measures of constructs were developed based on a comprehensive review of extant literature in low-carbon SCM, SCI, and logistics research. For each construct in this study, we developed a multiple-item measure to increase the construct validity. The measurement scale of LSPs' low-carbon SCI was comprised of 8 items adapted from $[8,24]$. Customer environmental requirement was measured by a 4 -item scale adapted from [38]. The measurement scale of corporate environmental responsibility contained 6 items adapted from [32,44]. Environmental performance was measured by 6 questions adapted from [31,48]. Finally, financial performance was measured using a 6-item scale adapted from [8]. All scales were 5-point Likert-type scales, where " 1 " indicated "strongly disagree" and "5" indicated "strongly agree."

Since most scales were adapted from measures in previous literature that were written in English, they were first translated into Chinese and then translated back into English by professional researchers. Then both versions of measures were compared item by item to ensure conformity. In addition, the survey was pre-tested on experts from both the industry and the academia and carefully revised according to their feedback on the clarity and face validity of the measures. 


\section{Research Results and Discussions}

\subsection{Analysis and Results}

To test the construct reliability, we performed exploratory factor analysis (EFA) in SPSS24.0 to assess unidimensionality of the scales and calculated the Cronbach's $\alpha$ value for each construct to evaluate internal consistency. Table 2 presents the measurement items and the overall reliability and validity of the measures.

As shown in Table 2, the Cronbach's $\alpha$ values of all constructs ranged from 0.85 to 0.94 , suggesting high reliability and internal consistency of the measures. Further, the composite reliability (CR) estimation of each construct exceeded the recommended threshold of 0.70 , thereby indicating good reliability of the multi-item scale.

Table 2. Reliability and validity of the measures.

\begin{tabular}{|c|c|c|c|c|c|}
\hline Construct & Items & Factor Loading & CR & Cronbach's alpha & AVE \\
\hline \multirow{4}{*}{$\begin{array}{l}\text { Corporate } \\
\text { environmental } \\
\text { responsibility } \\
\text { (CER) }\end{array}$} & $\begin{array}{l}\text { 1. My company is responsible for reducing } \\
\text { environmental pollutions in logistics activities. }\end{array}$ & 0.838 & \multirow{4}{*}{0.942} & \multirow{4}{*}{0.940} & \multirow{4}{*}{0.731} \\
\hline & $\begin{array}{l}\text { 3. My company is responsible for saving energy and } \\
\text { resources. }\end{array}$ & 0.837 & & & \\
\hline & $\begin{array}{l}\text { 5. My company is responsible for prevention and } \\
\text { regulation of logistics pollution. }\end{array}$ & 0.819 & & & \\
\hline & $\begin{array}{l}\text { 6. My company is committed to environmental } \\
\text { management. }\end{array}$ & 0.837 & & & \\
\hline \multirow{2}{*}{$\begin{array}{l}\text { Customer } \\
\text { environmental } \\
\text { requirement } \\
\text { (UER) }\end{array}$} & $\begin{array}{l}\text { 3. My customers only outsource their logistics } \\
\text { service to LSPs who are environmentally responsible. }\end{array}$ & 0.733 & \multirow{2}{*}{0.876} & \multirow{2}{*}{0.850} & \multirow{2}{*}{0.641} \\
\hline & $\begin{array}{l}\text { 4. My customers will retract the logistics outsourcing } \\
\text { contract if LSPs fail to satisfy their environmental } \\
\text { requirement. }\end{array}$ & 0.917 & & & \\
\hline \multirow{6}{*}{$\begin{array}{l}\text { LSPs' }^{\prime} \\
\text { low-carbon SCI } \\
\text { (LCSCI) }\end{array}$} & $\begin{array}{l}\text { 1. My company helps the customers and their } \\
\text { supply chains with the plan of low-carbon logistics } \\
\text { integration. }\end{array}$ & 0.773 & \multirow{6}{*}{0.924} & \multirow{6}{*}{0.924} & \multirow{6}{*}{0.604} \\
\hline & $\begin{array}{l}\text { 2. My company helps the customers and their } \\
\text { supply chains with the design of low-carbon } \\
\text { logistics integration. }\end{array}$ & 0.831 & & & \\
\hline & $\begin{array}{l}\text { 5. My company helps the customers and their } \\
\text { supply chains with knowledge transfer for } \\
\text { low-carbon logistics integration. }\end{array}$ & 0.734 & & & \\
\hline & $\begin{array}{l}\text { 6. My company helps the customers and their } \\
\text { supply chains with technical support for low-carbon } \\
\text { logistics integration. }\end{array}$ & 0.842 & & & \\
\hline & $\begin{array}{l}\text { 7. My company helps the customers and their } \\
\text { supply chains with achieving the environmental } \\
\text { goals based on low-carbon logistics integration. }\end{array}$ & 0.803 & & & \\
\hline & $\begin{array}{l}\text { 8. My company becomes strategic partner of the } \\
\text { customers on low-carbon logistics and supply chain } \\
\text { integration. }\end{array}$ & 0.717 & & & \\
\hline
\end{tabular}


Table 2. Reliability and validity of the measures.

\begin{tabular}{|c|c|c|c|c|c|}
\hline Construct & Items & Factor Loading & CR & Cronbach's alpha & AVE \\
\hline \multirow{4}{*}{$\begin{array}{l}\text { Financial } \\
\text { performance } \\
(\mathrm{FP})\end{array}$} & 1. Increased market competitiveness & 0.618 & \multirow{4}{*}{0.916} & \multirow{4}{*}{0.923} & \multirow{4}{*}{0.649} \\
\hline & 2. Increased revenue & 0.767 & & & \\
\hline & 4. Reduced logistics cost & 0.862 & & & \\
\hline & 5. Increased profit & 0.914 & & & \\
\hline \multirow{4}{*}{$\begin{array}{l}\text { Environmental } \\
\text { performance } \\
\text { (EP) }\end{array}$} & 1. Reduced pollution in logistics activities & 0.702 & \multirow[b]{4}{*}{0.924} & \multirow[b]{4}{*}{0.924} & \multirow[b]{4}{*}{0.671} \\
\hline & 2. Reduced cost of green operation & 0.862 & & & \\
\hline & 3. Reduced energy consumption in logistics activities & 0.866 & & & \\
\hline & $\begin{array}{l}\text { 4. Reduced cost of energy consumption in logistics } \\
\text { activities }\end{array}$ & 0.889 & & & \\
\hline
\end{tabular}

CR_composite reliability; AVE—average variance extracted.

To test the construct validity, both convergent validity and discriminant validity were assessed. As to the convergent validity, the confirmatory factor analysis (CFA) model fit indices were $\chi 2=623.986$, $\chi 2 / \mathrm{df}=1.617, \mathrm{CFI}=0.921, \mathrm{NNFI}=0.911, \mathrm{RMSEA}=0.071$, indicating good model fit. The average variance extracted (AVE) estimates exceeded the threshold value of 0.5 so that the convergent validity was ensured. The standardized factor loadings ranged from 0.688 to 0.917 , and t-tests showed that all the factor loadings were higher than 0.6 at the $p<0.001$ level, indicating that all items were strongly loaded on the constructs that they were expected to measure.

Further, the descriptive statistics and correlations of these constructs are presented in Table 3. It is clear that all square roots of the AVE values were higher than the corresponding correlations, indicating good discriminant validity. In addition, none of the correlation coefficients exceeded 0.7, suggesting that multicollinearity should not be a serious problem in this study.

Table 3. Descriptive statistics, correlation, and discriminant validity.

\begin{tabular}{cccccccc}
\hline & Mean & Std. Dev & CER & UER & LCSCI & FP & EP \\
\hline CER & 3.92 & 0.82 & 0.855 & & & & \\
UER & 3.61 & 0.78 & $0.516^{* * *}$ & 0.801 & & & \\
LCSCI & 3.92 & 0.69 & $0.602^{* * *}$ & $0.470^{* * *}$ & 0.777 & & \\
FP & 3.56 & 0.81 & $0.521^{* * *}$ & $0.519^{* * *}$ & $0.343^{* *}$ & 0.806 & 0.819 \\
EP & 3.74 & 0.79 & $0.555^{* * *}$ & $0.443^{* * *}$ & $0.271^{* *}$ & $0.688^{* * *}$ & $0.011^{* * *} p<0.001$ The value in the last cell in each row is the square root of AVE.
\end{tabular}

Then the structural equation model (SEM) was estimated using the maximum likelihood estimation method in AMOS 22.0. The overall fits of the SEM were $\chi 2=655.859, \mathrm{df}=388, \chi 2 / \mathrm{df}=1.690<3$, $\mathrm{CFI}=0.911, \mathrm{IFI}=0.912, \mathrm{TLI}=0.900, \mathrm{RMSEA}=0.075<0.08$, indicating good overall fit. As shown in Figure 2, the SEM results indicate that corporate environmental responsibility $(\beta=0.493, p<0.001$ ) and customer environmental requirement $(\beta=0.228, p<0.05)$ have positive relationships with LSPs' low-carbon SCI, thereby supporting H1 and H2, respectively. Further, LSPs' low-carbon SCI had a positive effect on LSPs' environmental performance $(\beta=0.302, p<0.01)$ as well as financial performance ( $\beta=0.169, p<0.05)$, thereby supporting $\mathrm{H} 3$ and $\mathrm{H} 4$, respectively. In addition, it was found that the LSPs' environmental performance had a positive relationship with financial performance $(\beta=0.661$, $p<0.001)$, thereby supporting H5. 


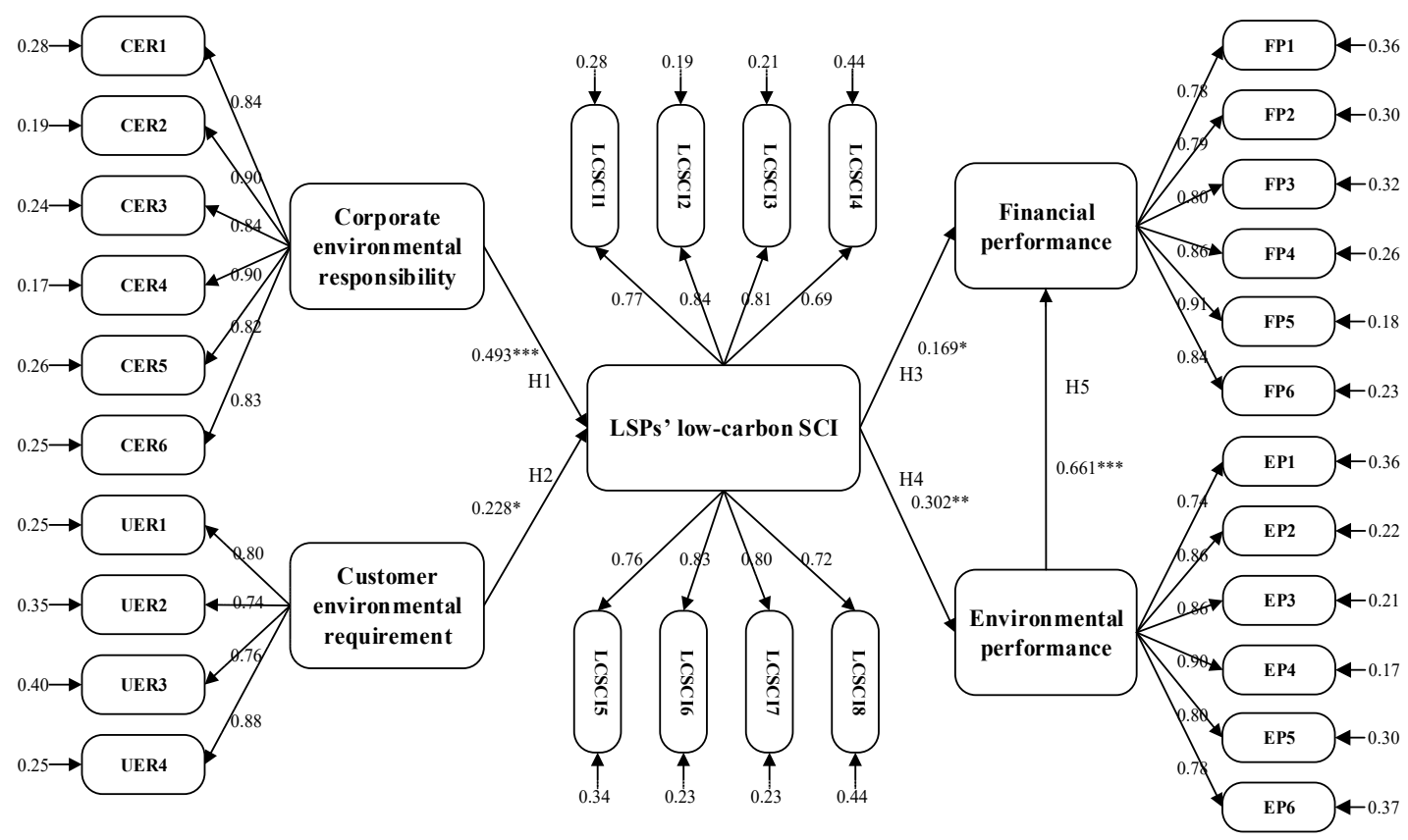

Figure 2. Estimated structural equation model.

\subsection{Discussion of Results}

Our results showed that LSPs' corporate environmental responsibility was a critical internal driver of LSPs' low-carbon SCI. From the relational view, corporate environmental responsibility represented voluntary commitment to sustainable development and a long-term relationship with the stakeholders, which lead to more environmental collaborations, including low-carbon SCI. Our finding is consistent with previous research on corporate social responsibility (CSR) in the logistics research [40], which maintains that the more social responsibility LSPs have, the more they value environmental sustainability, and hence the more willing they are to commit to environmentally-friendly activities. In this sense, our finding highlights the importance of corporate environmental responsibility in low-carbon supply chain initiatives and low carbon SCM.

We also revealed that customer environmental requirement is an important external driver of LSPs' low-carbon SCI. From the relational view, when the customers had stricter environmental requirement, to establish, maintain, and foster the buyer-supplier relationships, the LSPs would face more external pressure and, thereby, be more motivated to adopt the strategy of low-carbon SCI. This result is also consistent with previous research in low-carbon SCM showing that buyer requests or environmental criteria may have positive effects on suppliers' decisions of green supply chain practices or low-carbon initiatives in supply chains [12,38].

Further, our results showed that LSPs' low-carbon SCI was positively related to LSPs' environmental performance as well as their financial performance, indicating that with the strategy of low-carbon SCI, it is feasible for LSPs to achieve the goal of improving environmental and financial performances simultaneously. This finding is consistent with previous research on the effect of external low-carbon SCI from the perspective of manufacturers (rather than the LSPs) [8]. When the LSPs adopt the strategy of low-carbon SCI, such as helping the customers with the plan, design, and implementation of low-carbon logistics integration as well as the information sharing, knowledge transfer, and technical support, the LSPs can obtain higher environmental performance and financial performance simultaneously, from the strengthened relationship with the customers, as well as enhanced inter-organizational capabilities.

In addition, this study revealed a positive relationship between LSPs' environmental performance and their financial performance, suggesting that pursuing environmental performance is not necessarily in conflict with financial performance for LSPs; rather, environmental performance can be a source 
of financial performance in the logistics industry. On the one hand, this finding provides empirical evidence that logistics companies can improve their operational efficiency and financial performance by committing to environmentally-sustainable product design and logistics. On the other hand, this finding highlights the importance of the environmental reputation of LSPs in their SCM.

\section{Conclusions}

Motivated by the increasing challenge of climate change on SCM and the evolving role of LSPs as the resource integrator in supply chains, this study takes the perspective of LSPs and investigates the drivers and outcomes of LSPs' low-carbon SCI. A conceptual framework based on the relational view was proposed and tested using survey data from 124 Chinese LSPs. The results show that corporate environmental responsibility and customer environmental requirement are critical drivers of LSPs' low-carbon SCI, and that LSPs' low-carbon SCI has a positive effect on LSPs' environmental performance and financial performance. In addition, LSPs' environmental performance is shown to be positively related to LSPs' financial performance.

By investigating the drivers and outcomes of LSPs' low-carbon SCI, this research not only reveals internal and external factors that motivate LSPs to adopt the strategy of low-carbon SCI, but also shows that LSPs can improve environmental performance and financial performance simultaneously to achieve sustainable development. Our findings highlight the importance of SCI as a strategic approach in low-carbon SCM.

As to the managerial implications, our findings indicate that with external pressure from the customers on low carbon logistics, as well as internal pressure of corporate environmental responsibility, logistics companies are able to and should actively adopt the strategy of low-carbon SCI as a practice towards carbon emission reduction and sustainable development. This strategy will not only improve LSPs' environmental and financial performance in the short term, but also contribute to the management of customer relationship for LSPs in the long run.

As the first attempt of research on low-carbon SCI from the perspective of LSPs, rather than from the manufacturers, this research is limited in several aspects. First, we only considered two drivers of LSPs' low-carbon SCI (i.e., corporate environmental responsibility and customer environmental requirement) and did not consider other factors which may also have an effect, such as climate change regulation [12] and organizational cultures [33]. Second, the sample companies were from one province in China, with a sample size of 124 , due to the difficulty in data collection. The generality could be improved by collecting data with a larger sample size from multiple regions [7]. Third, due to the availability of data, we were not able to consider the effect of LSPs' low-carbon SCI on the environmental performance and financial performance of the entire supply chain. In addition, we did not consider different dimensions of LSPs' low-carbon SCI, such as internal integration, supplier integration, and customer integration [6]. It would be ideal for future research to investigate the roles of more drivers of LSPs' low-carbon SCI and the effects of various dimensions of LSPs' low-carbon SCI on firm performance, or even supply chain performance, using a sample with a larger size from more regions.

Author Contributions: C.Q. proposed the theoretical framework and drafted this manuscript. S.W. performed the data analysis. X.L. developed the concept and design, collected the data, validated the analysis, and revised the manuscript. X.Z. assisted in data curation and analysis.

Funding: This research is supported by a grant from the Humanity and Social Science Foundation of Ministry of Education of China (18YJC630134).

Conflicts of Interest: The authors declare no conflicts of interest.

\section{References}

1. United Nation. Goal 13: Take Urgent Action to Combat Climate Change and Its Impacts. Available online: https://www.un.org/sustainabledevelopment/climate-change-2/ (accessed on 22 April 2019). 
2. Liu, X. China-based logistics research: A review of the literature and its implications. Int. J. Phys. Distrib. Logist. Manag. 2014, 44, 392-411. [CrossRef]

3. Sindi, S.; Roe, M. The Evolution of Supply Chains and Logistics. In Strategic Supply Chain Management; Palgrave Macmillan: Cham, Switzerland, 2017; pp. 7-25.

4. Zacharia, Z.G.; Sanders, N.R.; Nix, N.W. The emerging role of the third-party logistics provider (3PL) as an orchestrator. J. Bus. Logist. 2011, 32, 40-54. [CrossRef]

5. Ameknassi, L.; Ait-Kadi, D.; Rezg, N. Integration of logistics outsourcing decisions in a green supply chain design: A stochastic multi-objective multi-period multi-product programming model. Int. J. Prod. Econ. 2016, 182, 165-184. [CrossRef]

6. Flynn, B.B.; Huo, B.; Zhao, X. The impact of supply chain integration on performance: A contingency and configuration approach. J. Oper. Manag. 2010, 28, 58-71. [CrossRef]

7. Huo, B.; Liu, C.; Chen, H.; Zhao, X. Dependence, trust, and 3PL integration: An empirical study in China. Int. J. Phys. Distrib. Logist. Manag. 2017, 47, 927-948. [CrossRef]

8. Mao, Z.; Zhang, S.; Li, X. Low carbon supply chain firm integration and firm performance in China. J. Clean. Prod. 2017, 153, 354-361. [CrossRef]

9. Dyer, J.H.; Singh, H. The relational view: Cooperative strategy and sources of interorganizational competitive advantage. Acad. Manag. Rev. 1998, 23, 660-679. [CrossRef]

10. Chen, I.J.; Paulraj, A. Towards a theory of supply chain management: The constructs and measurements. J. Oper. Manag. 2004, 22, 119-150. [CrossRef]

11. Das, C.; Jharkharia, S. Low carbon supply chain: A state-of-the-art literature review. J. Manuf. Technol. Manag. 2018, 29, 398-428. [CrossRef]

12. Damert, M.; Feng, Y.; Zhu, Q.; Baumgartner, R.J. Motivating low-carbon initiatives among suppliers: The role of risk and opportunity perception. Resour. Conserv. Recycl. 2018, 136, 276-286. [CrossRef]

13. Jabbour, A.; Jabbour, C.; Sarkis, J.; Gunasekaran, A.; Alves, M.; Ribeiro, D. Decarbonisation of operations management-looking back, moving forward: A review and implications for the production research community. Int. J. Prod. Res. 2018, 1-23. [CrossRef]

14. Srivastava, S.K. Green supply-chain management: A state-of-the-art literature review. Int. J. Manag. Rev. 2007, 9, 53-80. [CrossRef]

15. Zhu, Q.; Geng, Y. Drivers and barriers of extended supply chain practices for energy saving and emission reduction among Chinese manufacturers. J. Clean. Prod. 2013, 40, 6-12. [CrossRef]

16. Zhang, B.; Wang, Z. Inter-firm collaborations on carbon emission reduction within industrial chains in China: Practices, drivers and effects on firms' performances. Energy Econ. 2014, 42, 115-131. [CrossRef]

17. Lieb, K.J.; Lieb, R.C. Environmental sustainability in the third-party logistics (3PL) industry. Int. J. Phys. Distrib. Logist. Manag. 2010, 40, 524-533. [CrossRef]

18. Colicchia, C.; Marchet, G.; Melacini, M.; Perotti, S. Building environmental sustainability: Empirical evidence from Logistics Service Providers. J. Clean. Prod. 2013, 59, 197-209. [CrossRef]

19. Centobelli, P.; Cerchione, R.; Esposito, E. Environmental sustainability in the service industry of transportation and logistics service providers: Systematic literature review and research directions. Trans. Res. D 2017, 53, 454-470. [CrossRef]

20. Herold, D.M.; Lee, K.H. Carbon management in the logistics and transportation sector: An overview and new research directions. Carbon Manag. 2017, 8, 79-97. [CrossRef]

21. Herold, D.M.; Lee, K.H. Carbon disclosure strategies in the global logistics industry: Similarities and differences in carbon measurement and reporting. In Pathways to a Sustainable Economy; Springer: Cham, Switzerland, 2018; pp. 87-101.

22. Herold, D.M.; Lee, K.H. The influence of the sustainability logic on carbon disclosure in the global logistics industry: The case of Dhl, Fdx and Ups. Sustainability 2017, 9, 601. [CrossRef]

23. Herold, D.M.; Lee, K.H. The influence of internal and external pressures on carbon management practices and disclosure strategies. Australas. J. Environ. Manag. 2019, 26, 63-81. [CrossRef]

24. Jayaram, J.; Tan, K.C. Supply chain integration with third-party logistics providers. Int. J. Prod. Econ. 2010, 125, 262-271. [CrossRef] 
25. Liu, C.H.; Lai, P.Y. Impact of external integration capabilities of third-party logistics providers on their financial performance. Int. J. Logist. Manag. 2016, 27, 263-283. [CrossRef]

26. Liu, C.L.; Lee, M.Y. Integration, supply chain resilience, and service performance in third-party logistics providers. Int. J. Logist. Manag. 2018, 29, 5-21. [CrossRef]

27. Shang, K.C. Integration and organizational learning capabilities in third-party logistics providers. Serv. Ind. J. 2009, 29, 331-343. [CrossRef]

28. Vachon, S.; Klassen, R.D. Extending green practices across the supply chain: The impact of upstream and downstream integration. Int. J. Oper. Prod. Manag. 2006, 26, 795-821. [CrossRef]

29. Vachon, S.; Klassen, R.D. Environmental management and manufacturing performance: The role of collaboration in the supply chain. Int. J. Prod. Econ. 2008, 111, 299-315. [CrossRef]

30. Lo, S.M.; Shiah, Y.A. Associating the motivation with the practices of firms going green: The moderator role of environmental uncertainty. Supply Chain Manag. Int. J. 2016, 21, 485-498. [CrossRef]

31. Doran, J.; Ryan, G. The importance of the diverse drivers and types of environmental innovation for firm performance. Bus. Strategy Environ. 2016, 25, 102-119. [CrossRef]

32. Huang, Y.C.; Huang, C.H.; Yang, M.L. Drivers of green supply chain initiatives and performance: Evidence from the electrical and electronics industries in Taiwan. Int. J. Phys. Distrib. Logist. Manag. 2017, 47, 796-819. [CrossRef]

33. Cao, Z.; Huo, B.; Li, Y.; Zhao, X. The impact of organizational culture on supply chain integration: A contingency and configuration approach. Supply Chain Manag. Int. J. 2015, 20, 24-41. [CrossRef]

34. Huo, B.; Han, Z.; Prajogo, D. Antecedents and consequences of supply chain information integration: A resource-based view. Supply Chain Manag. Int. J. 2016, 21, 661-677. [CrossRef]

35. Barney, J.B. Firm resources and sustained competitive advantage. J. Manag. 1991, 17, 99-120. [CrossRef]

36. Gölgeci, I.; Gligor, D.M.; Tatoglu, E.; Arda, O.A. A relational view of environmental performance: What role do environmental collaboration and cross-functional alignment play? J. Bus. Res. 2019, 96, 35-46. [CrossRef]

37. Luo, J.; Chong, Y.L.; Ngai, E.W.T.; Liu, M.J. Reprint of "green supply chain collaboration implementation in China: The mediating role of guanxi". Trans. Res. E 2015, 74, 37-49. [CrossRef]

38. Wolf, C.; Seuring, S. Environmental impacts as buying criteria for third party logistical services. Int. J. Phys. Distrib. Logist. Manag. 2010, 40, 84-102. [CrossRef]

39. Carter, C.R.; Jennings, M.M. Logistics social responsibility: An integrative framework. J. Bus. Logist. 2002, 23, 145-180. [CrossRef]

40. Piecyk, M.I.; Björklund, M. Logistics service providers and corporate social responsibility: Sustainability reporting in the logistics industry. Int. J. Phys. Distrib. Logist. Manag. 2015, 45, 459-485. [CrossRef]

41. Kovács, G. Corporate environmental responsibility in the supply chain. J. Clean. Prod. 2008, 16, 1571-1578. [CrossRef]

42. Hsu, C.; Tan, K.C.; Zailani, S.; Jayaraman, V. Supply chain drivers that foster the development of green initiatives in an emerging economy. Int. J. Oper. Prod. Manag. 2013, 33, 656-688. [CrossRef]

43. Laosirihongthong, T.; Adebanjo, D.; Tan, K.C. Green supply chain management practices and performance. Ind. Manag. Data Syst. 2013, 113, 1088-1109. [CrossRef]

44. Zhu, Q.; Sarkis, J.; Lai, K.H. Institutional-based antecedents and performance outcomes of internal and external green supply chain management practices. J. Purch. Supply Manag. 2014, 19, 106-117. [CrossRef]

45. Aharonovitz, M.; Vieira, J.; Suyama, S. How logistics performance is affected by supply chain relationships. Int. J. Logist. Manag. 2018, 29, 284-307. [CrossRef]

46. Tachizawa, E.M.; Gimenez, C.; Sierra, V. Green supply chain management approaches: Drivers and performance implications. Int. J. Oper. Prod. Manag. 2015, 35, 1546-1566. [CrossRef]

47. Rao, P.; Holt, D. Do green supply chains lead to competitiveness and economic performance? Int. J. Oper. Prod. Manag. 2013, 25, 898-916. [CrossRef]

48. Mitra, S.; Datta, P.P. Adoption of green supply chain management practices and their impact on performance: An exploratory study of Indian manufacturing firms. Int. J. Prod. Res. 2014, 52, 2085-2107. [CrossRef] 
49. Guangdong Logistics Profession Association. Key Indices of the Logistics Sector in Guangdong in 2017. Available online: http://www.wlhyxh.com/show-42-5962-1.html (accessed on 22 April 2019). (In Chinese).

50. Armstrong, J.S.; Overton, T.S. Estimating nonresponse bias in mail surveys. J. Mark. Res. 1977, 14, $396-402$. [CrossRef]

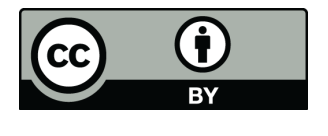

(C) 2019 by the authors. Licensee MDPI, Basel, Switzerland. This article is an open access article distributed under the terms and conditions of the Creative Commons Attribution (CC BY) license (http://creativecommons.org/licenses/by/4.0/). 